\title{
Heat Release Rafe Characterization of NFPA 1403 Compliant Training Fuels
}

\author{
John W. Regan (D*, Underwriters Laboratories Inc, 333 Pfingsten Rd, \\ Northbrook, IL 60062, USA
}

Received: 14 May 2020/Accepted: 6 January 2021/Published online: 10 February 2021

\begin{abstract}
When using solid fuels for live fire training, NFPA 1403: Standard on Live Fire Training Evolutions requires that the materials be wood based. While the standard offers guidance on the type of fuels that are permissible for use in training, it offers little in the way of quantitative methods of selecting an appropriately sized fuel package. In order to examine the effects of fuel mass and orientation on heat release behavior, free burn heat release rate (HRR) experiments were conducted on twentyone wood-based training fuel packages and twelve comparison furniture items. Training fuel packages demonstrated peak HRRs ranging from 1.0 MW to 3.6 MW, with the total energy release between $210 \mathrm{MJ}$ and $1615 \mathrm{MJ}$. The furniture items exhibited peak HRRs between 0.9 MW and $3.7 \mathrm{MW}$, with the total energy release between $180 \mathrm{MJ}$ and $995 \mathrm{MJ}$. A least-squares linear regression analysis indicated a good linear fit between total energy release and fuel mass burned among the training fuel packages $\left(\mathrm{R}^{2}=0.98\right)$, suggesting that the effective heat of combustion is approximately constant at $14.2 \mathrm{MJ} / \mathrm{kg}$. Generally, peak HRR increased as initial fuel mass increased, although the relationship was more variable, with the peak HRRs of similarly sized training fuel packages varying by nearly $1 \mathrm{MW}$. The results indicated that while total energy release was dependent largely on the initial fuel mass, peak HRR and peak burning duration were also dependent on the orientation and type of fuel in the fuel package. Wood-based training fuel packages were capable of producing peak HRRs comparable to individual items of furniture, although the total energy release was typically higher for the training fuel packages compared to corresponding furniture items.
\end{abstract}

Keywords: NFPA 1403, Firefighter training, Live fire training fuel packages

\section{Introduction}

Firefighter training commonly includes participation in live fire training evolutions in preparation for the real-world fire ground situations that firefighters will face. NFPA 1403: Standard on Live Fire Training Evolutions is the standard which outlines the minimum requirements for conducting live fire training in acquired and fixed facility training structures [17]. The standard was established in part due to a 1982 incident in Colorado, in which two firefighters died and two more were injured after an uncontrolled flashover occurred during a training evolution in an

\footnotetext{
*Correspondence should be addressed to: John W. Regan, E-mail: jack.regan@ul.org
} 
abandoned storage shed. An after action report identified several contributing factors to the incident, among which was an inappropriate fuel load including tires, crankcase oil, and flammable fiberboard ceiling tiles [5].

The purpose of NFPA 1403 is to provide a procedure for conducting live fire training so that learning objectives are achieved and health and safety hazards are minimized. The standard requires that fuel materials used in the fuel package shall be only wood products, defining acceptable fuels as "pine excelsior, wooden pallets, straw, hay, and other wood-based products" [17]. The standard specifically forbids "pressure-treated wood products, rubber, plastic, polyurethane foam, tar paper, upholstered furniture, carpeting, and chemically treated or pesticide treated straw or hay" as fuels.

While NFPA 1403 provides detail about the types of fuel that can be used, it offers less definitive guidance about the quantity of fuel. The lack of quantitative guidance in NFPA 1403 often leads departments or training institutions to specify a quantity of fuel, often in the form of a number of pallets, independent of the pallet size, fuel load geometry, and the size and ventilation profile of the compartment in which they are being burned. With different fuel materials, such as engineered wood-based materials, becoming more popular, quantitative guidance is essential to support NFPA 1403 and empower instructors to conduct safe live fire training.

In order to offer a more quantitative method of designing live fire training evolutions, the 2018 edition of NFPA 1403 includes a methodology for conducting ventilation-controlled training fires. The importance of conducting this type of training was highlighted by fire service research which indicated that fires in residential structures with synthetic furnishings have an increased propensity to be ventilation controlled at the time of fire department arrival [12]. Appendix A.4.13.7 of this standard includes Babrauskas' equation [2] to determine the minimum heat release rate (HRR) required for flashover in a compartment, as shown in Equation 1,

$$
\dot{Q}=750 A_{o} \sqrt{H_{o}}
$$

where $\dot{Q}$ is the heat release rate, $A_{o}$ is the area of the vent and $H_{o}$ is the height of the vent. Although the standard provides this equation, it provides no data for firefighters to estimate the peak HRR of a fuel package they might choose.

In addition to the lack of quantitative guidance on choosing a training fuel package, the disparity between the wood-based fuels that firefighters are permitted to use for live fire training and the synthetic fuels which firefighters are likely to encounter with the residential fireground brings forth an important juxtaposition: the fire dynamics in training fires conducted with wood-based fuels in training facilities may not be representative of the ventilation-controlled fire dynamics observed in residential fires with synthetic fuels. A study by Horn et al [10] compared peak temperatures measured at firefighter operating height during three types of training fire evolutions with temperatures measured during a simulated residential structure fire and found that the temperatures were lower in the train- 
ing evolutions, particularly in areas remote from the fire. This research, combined with anecdotes among firefighters and fire instructors, has led to a perception that wood-based training fuels are not capable of producing thermal conditions consistent with those observed in residential structure fires $[8,9,20]$. The perception that training fires conducted with wood-based training fuels are unrealistic can tempt firefighters to include materials other than wood products in training fuel packages. The addition of these materials can result in unexpected fire growth, which has caused training-related line-of-duty deaths and injuries [15, 23, 26, 27]. Madrzykowski [15] investigated one such incident in Florida, where two firefighters died while conducting a search when the fire room transitioned to flashover [23]. As part of the investigation, the fire room and adjacent spaces were recreated, and the thermal conditions produced by five different combinations of fuel load were investigated, indicating that the thermal conditions in the fire room were unsurvivable for even a firefighter in full personal protective equipment (PPE).

While research into the firefighter training environment has focused on characterizing the thermal exposure to firefighters during training fires $[16,29]$ and on the physiological effects of firefighter training [10, 24], little work has been done to quantify the heat release characteristics of common training fuel packages. Limited heat release rate characterization has been conducted on wood-based training fuels as a part of reconstruction efforts after fatal fires [15] and as an inexpensive, repeatable fuel load to study fireground actions [1, 10]. Additionally, Krasner [11] conducted a series of experiments examining the HRR of stacks of pallets, which developed a correlation between stack height and peak HRR. Similarly, while research has been conducted to characterize the modern residential fire environment and emphasize the difference between modern and legacy residential fuels $[12,13]$, the differences between training fuels and synthetic furnishings is not as well characterized.

The purpose of this manuscript is to (1) to document the HRR characteristics of common NFPA 1403-compliant training fuel packages, (2) compare HRR characteristics of training fuels to furniture items, and (3) provide guidance to the fire service regarding fuel type, quantity, and orientation to complement the information provided in NFPA 1403.

\section{Methodology}

\subsection{Measures}

Heat release rate characterization was conducted on 21 NFPA 1403-compliant training fuel packages and 12 comparison fuel packages. The experiments were conducted in an oxygen consumption calorimetry lab. The oxygen consumption calorimeter [19] was located at UL's facility in Northbrook, IL, and was designed for a peak heat release rate of $10 \mathrm{MW}$. Fuel packages were placed on a load cell in order to capture mass loss data during the experiment. Bryant and Mullholland [4] estimate the expanded relative uncertainty of high heat release rate fires as $11 \%$.

The load cell had a range of $0 \mathrm{~kg}$ to $200 \mathrm{~kg}$ with a resolution of $0.05 \mathrm{~kg}$ and a calibration uncertainty within $1 \%$ [18]. The expanded uncertainty is estimated to 
be less than $\pm 5 \%$. It should be noted that the listed uncertainty for the load cell is for static measurements, and it is possible that the uncertainty for the dynamic mass loss measurements is greater.

\subsection{Fuel Packages}

All training fuel packages were composed of NFPA 1403-compliant, wood-based materials, including wooden pallets, straw, excelsior, dimensional lumber, oriented strand board (OSB), and medium density fiberboard (MDF). The excelsior bales were nominally $23 \mathrm{~kg}$ standard bales, measuring $0.40 \mathrm{~m} \times 0.45 \mathrm{~m} \times 0.86 \mathrm{~m}$ with 332 spur cut fibers. The straw bales were purchased from a local agricultural supplier and has an average mass of $15.8 \pm 2.3 \mathrm{~kg}$. The pallets used for all of the experiments were three-runner soft-wood pallets, nominally measuring 1.22 $\mathrm{m} \times 1.02 \mathrm{~m}$. The average mass of the pallets used in the HRR characterization experiments was $17.7 \pm 0.7 \mathrm{~kg}$. The engineered wood boards and dimensional lumber were purchased from a local hardware distributer. The training fuel loads were not conditioned under a specific ambient temperature or relative humidity, but were stored in an indoor storage area prior to testing. Twenty of the fuel packages rested on a $1.21 \mathrm{~m} \times 1.21 \mathrm{~m} \times 0.3 \mathrm{~m}$ tall steel frame, which sat atop the load frame. The remaining fuel package used a modified hooded frame assembly. Both of these frames are show in Fig. 1. Training fuel packages were ignited at a single location at the base of each fuel package by a laboratory technician using a propane torch.

Fuel materials were arranged in several different configurations. A technical panel of fire service professionals [22] identified several common geometries utilized by fire instructors across the United States, which are described in Table 1 and shown in Fig. 2. While budget and time restraints prevented multiple replicate experiments for each fuel package, the project technical panel designated a base fuel package, consisting of three pallets and one bale of straw in a triangle. Variations of this fuel package were evaluated to characterize the effects of including
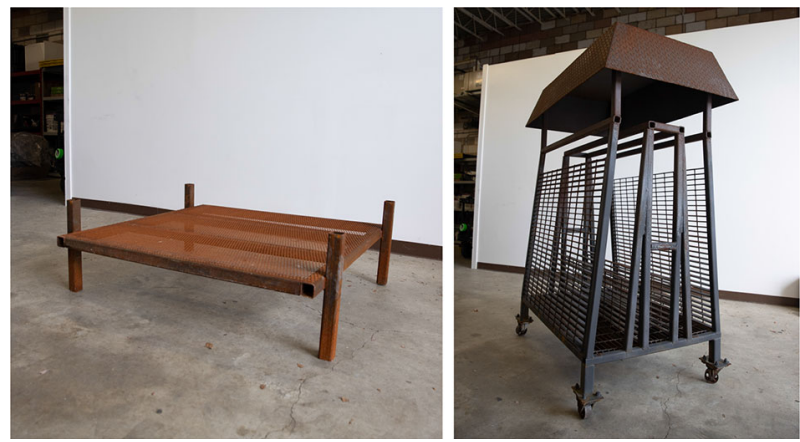

Figure 1. Training fuel racks used for heat release rate characterization experiments. Left image is the rack used for 20 of the 21 training fuel packages. Right image is the modified rack used for the remaining fuel package. 


\section{Table 1}

Descriptions of Orientations Used for Training Fuel Packages

\begin{tabular}{|c|c|}
\hline Name & Description \\
\hline Triangle (a.) & Three pallets arranged into a triangle configuration (Fig. 2, top left) \\
\hline Vertical Stack (b.) & $\begin{array}{l}\text { Pallets stacked vertically, with each pallet leaning against the one next to } \\
\text { it, as if they were leaning against a wall (Fig. } 2 \text {, top middle) }\end{array}$ \\
\hline Horizontal Stack (c.) & $\begin{array}{l}\text { Pallets stacked on top of each other, rather than next to each other } \\
\text { (Fig. 2, top right) }\end{array}$ \\
\hline Boxed Triangle (d.) & $\begin{array}{l}\text { Three pallets in a triangle, with fourth and fifth pallets on each open end } \\
\text { of the triangle, and a sixth pallet across the top (Fig. } 2 \text {, bottom left) }\end{array}$ \\
\hline Inverted Triangle (e.) & $\begin{array}{l}\text { Three pallets in a triangular platform, with an additional three pallets } \\
\text { vertically stacked on top of the platform (Fig. } 2 \text {, bottom middle) }\end{array}$ \\
\hline $\begin{array}{l}\text { Non-Traditional Wood- } \\
\text { Based Fuels (f.) }\end{array}$ & $\begin{array}{l}\text { Base fuel package with boards or dimensional lumber placed behind the } \\
\text { base fuel package, as if leaning against a wall (Fig. 2, bottom right) }\end{array}$ \\
\hline
\end{tabular}
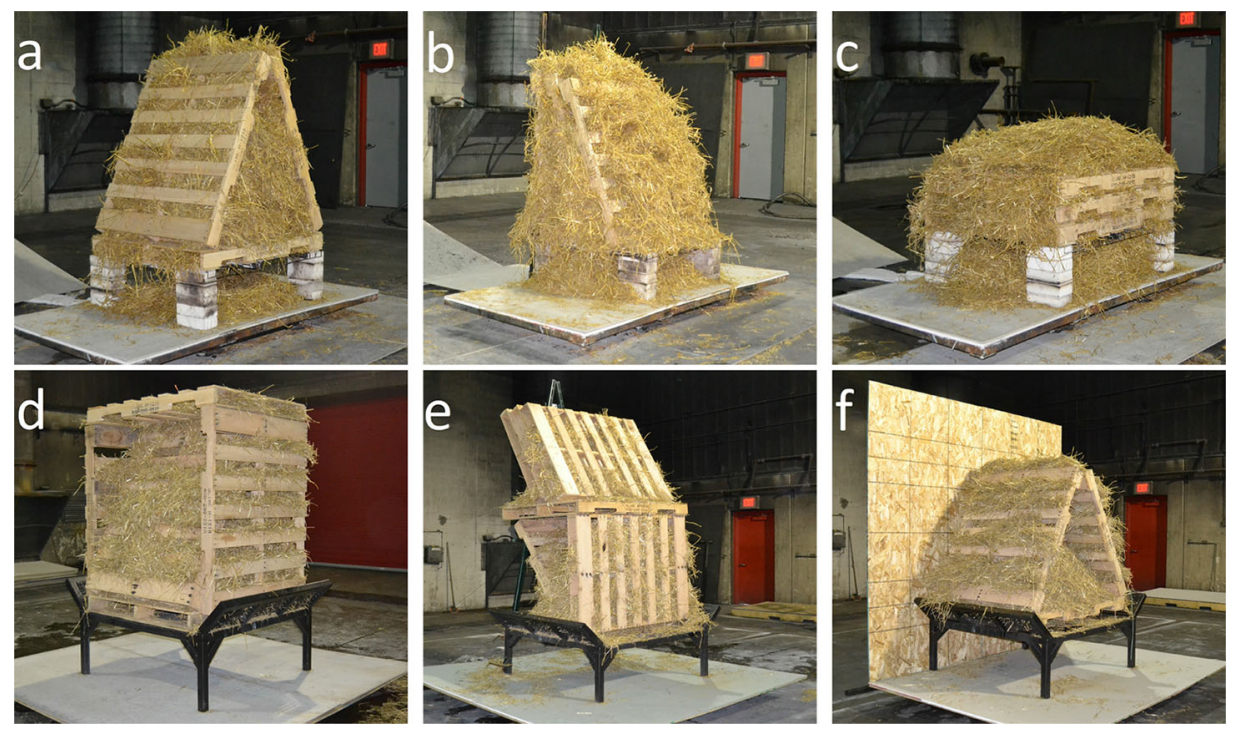

Figure 2. Images of orientations used for training fuel packages. Shown left to right, top to bottom are the triangle (a), vertical stack (b), horizontal stack (c), boxed triangle (d), inverted triangle (e), and non-traditional wood fuel (f) configurations.

additional pallets, straw, excelsior, or non-traditional wooden fuels in a similar formation. Other fuel configurations, identified in fire service trade literature by Garcia and Kaufmann [9] and Fisher [8], were included to examine the effects of fuel orientation on heat release behavior. Additionally, a review of existing literature identified contemporary fuels such as OSB, MDF, and dimensional lumber. 
These non-traditional training fuel materials were incorporated into the base fuel package in a manner described in Table 1.

The training fuel packages can be considered in seven groups, separated by the fuel materials used and the orientation.

- Base Fuel Package: Three replicates of three pallets with one bale of straw in a triangle, intended to examine the variability of a common fuel package.

- Light Fuels: Four fuel packages consisting of either one or two bales of straw or excelsior, intended to examine the heat release behavior of materials commonly used as "kindling" in training fuel packages.

- Pallets with Additional Light Fuels: Two fuel packages consisting of three pallets in a triangle with either two bales of straw or one bale of excelsior. Intended to examine the effects of different amounts of light fuels compared to the base fuel package.

- Alternate Three Pallet Configurations: Three fuel packages consisting of three pallets and one bale of straw, intended to examine how different fuel orientations affect the heat release behavior of a similar amount of pallets and straw.

- Vertically Stacked Pallets: Four fuel packages consisting of four, five, six, and seven vertically stacked pallets, each with one bale of straw. Intended to examine the effect of adding additional fuel mass in the form of additional pallets on heat release behavior, compared with 3 vertically stacked pallets and one bale of straw.

- Alternate Six Pallet Configurations: Two fuel packages consisting of six pallets and one bale of straw, intended to examine how different fuel orientations affect the heat release behavior of a similar amount of pallets and straw.

- Non-Traditional Wood Fuels: Three fuel packages consisting of the base fuel package with either two sheets of OSB, two sheets of MDF, or twelve pieces of dimensional lumber. Intended to examine how additional fuel mass in the form of engineered wood or dimensional lumber affects heat release behavior.

Table 2 lists the fuel packages evaluated in these experiments, their abbreviations, and their initial masses. The nomenclature used to label the fuel packages reflects the number of each type of wood-based fuel used and the orientation of the fuel within the fuel package. For example, 6P1S-V indicates that the fuel package consisted of 6 pallets, 1 bale of straw, arranged in a vertical stack.

Comparison fuel packages included residential furnishings, including upholstered sofas, chairs, and bedsets. Comparison fuel packages were remotely ignited using an electric matchbook. Ignition occurred in the cushion of the sofas and upholstered chairs, and in a plastic waste receptacle filled with newspaper for the bedsets. Table 3 describes each comparison fuel package.

\subsection{Analysis Techniques}

Quantities of interest included the peak heat release rate, total energy release, peak mass loss rate, peak burning duration, and effective heat of combustion 


\section{Table 2}

Training Fuel Package Descriptions for Heat Release Rate Characterization

Total mass

\begin{tabular}{llr}
\hline 3P1S-1 & 3 Pallets, arranged in a triangle, stuffed with 1 bale of straw (first replicate) & 70.1 \\
3P1S-2 & 3 Pallets, arranged in a triangle, stuffed with 1 bale of straw (second replicate) & 69.4 \\
3P1S-3 & 3 Pallets, arranged in a triangle, stuffed with 1 bale of straw (third replicate) & 69.8 \\
1S & 1 bale of straw, fluffed & 15.3 \\
2S & 2 Bales of straw, fluffed & 29.1 \\
1E & 1 Bale of excelsior, fluffed & 23.0 \\
2E & 2 Bales of excelsior, fluffed & 54.3 \\
3P2S & 3 Pallets, arranged in a triangle, stuffed with 2 bales of straw & 79.4 \\
3P1E & 3 Pallets, arranged in a triangle, stuffed with 1 bale of excelsior & 76.2 \\
3P1S-H & 3 Pallets, arranged horizontally, stuffed with 2 bales of straw & 69.8 \\
3P1S-R & 3 Pallets, stuffed with 1 bale of straw, arranged in a metal rack with a hood & 68.7 \\
3P1S-V & 3 Pallets, arranged vertically, stuffed with 1 bale of straw & 69.8 \\
4P1S-V & 4 Pallets, arranged vertically, stuffed with 1 bale of straw & 85.8 \\
5P1S-V & 5 Pallets, arranged vertically, stuffed with 1 bale of straw & 103.4 \\
6P1S-V & 6 Pallets, arranged vertically, stuffed with 1 bale of straw & 121.1 \\
7P1S-V & 7 Pallets, arranged vertically, stuffed with 1 bale of straw & 138.7 \\
6P1S- & 6 Pallets, stuffed with 1 bale of straw, with 3 pallets arranged into a triangle, & 121.3 \\
BT & one pallet placed on each end, and one over the top & \\
6P1S-IT & 6 Pallets, stuffed with 1 bale of straw, with pallets stacked to the ceiling. & 121.5 \\
3P1SO & 3 Pallets, arranged in a triangle, stuffed with 1 bale of straw, with two vertical & 111.1 \\
& 1.2 m x 2.4 m sheets of OSB & \\
3P1SM & 3 Pallets, arranged in a triangle, stuffed with 1 bale of straw, with two vertical & 120.8 \\
& 1.2 m x 2.4 m sheets of MDF & \\
3P1SDL & 3 Pallets, arranged in a triangle, stuffed with 1 bale of straw, with 12 vertical & 100.5 \\
& 25 mm x 152 mm boards of dimensional lumber &
\end{tabular}

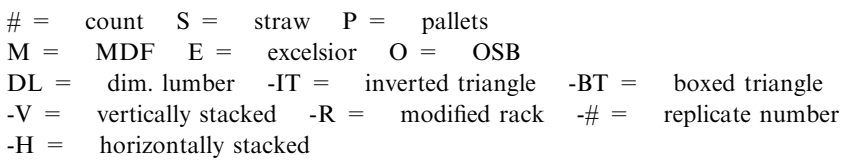

$\left(\Delta h_{c, e f f}\right)$. The heat release rate time histories were numerically integrated using an Euler scheme to compute the total energy release over the course of each heat release rate experiment. Mass loss rate data was smoothed using a 15 second moving average to mitigate noise in the signal. The analysis accounted for instantaneous changes in mass due to fuel falling off of the load cell over the course of the experiment. Due to fluctuations in the mass loss readings, the peak MLR reported in Sects. 3 and 4 is the average MLR taken over the peak burning period. The peak burning period is defined by Dillon [6] as the period in which the heat release rate was greater than or equal to $80 \%$ of the peak heat release rate. The effective heat of combustion was determined by dividing the total energy released over the course of the experiment by the change in mass over the course of the experiment, as shown in Eq. 2, 


\section{Table 3 \\ Comparison Fuel Package Descriptions for Heat Release Rate Characterization}

\section{Total}

Mass

Label

Fuel package

$(\mathrm{kg})$

SLI Upholstered sofa with wood frame, polyurethane cushions, polyester batting, and polyester microfiber covering ignited in the left arm

SCI Upholstered sofa with wood frame, polyurethane cushions, polyester batting, and polyester microfiber covering ignited in the center cushion

SRI Upholstered sofa with wood frame, polyurethane cushions, polyester batting, and polyester microfiber covering ignited in the right arm

SC-1 Striped upholstered armchair with wood frame, polyurethane cushion, polyester batting, and cloth covering (first replicate)

SC-2 Striped upholstered armchair with wood frame, polyurethane cushion, polyester batting, and cloth covering (second replicate)

SC-3 Striped upholstered armchair with wood frame, polyurethane cushion, polyester batting, and cloth covering (third replicate)

YC-1 Yellow upholstered armchair with wood frame, polyurethane cushion, polyester batting, and cloth covering (first replicate)

YC-2 Yellow upholstered armchair with wood frame, polyurethane cushion, polyester batting, and cloth covering (second replicate)

B-1 Bed set consisting of metal stand, box spring, mattress, 4 in. polyurethane foam pad, comforter, and pillows (first replicate)

B-2 Bed set consisting of metal stand, box spring, mattress, 4 in. polyurethane foam pad, comforter, and pillows (second replicate)

BC-1 Barrel-type chair with a polyurethane foam cushion and an expanded polystyrene frame.

KS-1 Kit sofa with a wood frame and polyurethane upholstery.

$\mathrm{B}=$ bed $\mathrm{S}=$ upholstered sofa $\mathrm{LI}=$ left ignition

$\mathrm{CI}=$ center ignition $\mathrm{RI}=$ right ignition $\mathrm{SC}=$ striped chair

$\mathrm{BC}=$ barrel chair $\mathrm{KS}=$ kit sofa $\mathrm{YC}=$ yellow chair

$-\#=$ replicate number

$$
\Delta h_{c, e f f}=\frac{Q_{\text {total }}}{\Delta m_{\text {total }}}
$$

where $\Delta h_{c, e f f}$ is the effective heat of combustion, $Q_{\text {total }}$ is the total energy release, and $\Delta m_{\text {total }}$ is the change in mass from the start to the end of the experiment.

In order to explore the relationship between parameters such as the initial fuel mass, the peak HRR, the total energy, and the peak MLR, an ordinary leastsquares linear regression was conducted. 


\section{Table 4}

Training Fuel Package Heat Release Rate (HRR) Characterization Results

\begin{tabular}{lccccc}
\hline Label & $\begin{array}{c}\text { Peak } \\
\text { HRR } \\
(\mathrm{MW})\end{array}$ & $\begin{array}{c}\text { Peak } \\
\text { MLR* } \\
(\mathrm{kg} / \mathrm{s})\end{array}$ & $\begin{array}{c}\text { Total Energy } \\
\text { Releas } \\
(\mathrm{MJ})\end{array}$ & $\begin{array}{c}\Delta h_{c, \text { eff }} \\
(\mathrm{MJ} / \mathrm{kg})\end{array}$ & $\begin{array}{c}\text { Peak Burning } \\
\text { Duration } \\
(\mathrm{s})\end{array}$ \\
\hline 3P1S-1 & 1.9 & 0.15 & 855 & 12.4 & 152 \\
3P1S-2 & 1.6 & 0.13 & 820 & 12.7 & 291 \\
3P1S-3 & 2.1 & 0.15 & 880 & 13.1 & 120 \\
1S & 1.0 & 0.10 & 210 & 16.4 & 66 \\
2S & 2.1 & 0.15 & 390 & 14.4 & 61 \\
1E & 1.7 & 0.13 & 325 & 14.2 & 90 \\
2E & 1.6 & 0.12 & 785 & 14.2 & 257 \\
3P2S & 2.5 & 0.17 & 1195 & 15.5 & 218 \\
3P1E & 3.0 & 0.20 & 1060 & 14.1 & 82 \\
3P1S-R & 1.6 & 0.13 & 929 & 14.6 & 366 \\
3P1S-H & 1.2 & 0.11 & 925 & 12.8 & 419 \\
3P1S-V & 2.0 & 0.15 & 815 & 12.5 & 317 \\
4P1S-V & 2.3 & 0.17 & 1025 & 13.3 & 299 \\
5P1S-V & 2.9 & 0.20 & 1340 & 14.0 & 167 \\
6P1S-V & 3.2 & 0.22 & 1575 & 14.0 & 244 \\
7P1S-V & 3.4 & 0.24 & 1815 & 13.9 & 214 \\
6P1S-BT & 3.6 & 0.25 & 1580 & 13.6 & 225 \\
6P1S-IT & 3.8 & 0.27 & 1605 & 14.4 & 167 \\
3P1SO & 2.4 & 0.17 & 1550 & 15.1 & 209 \\
3P1SM & 2.7 & 0.19 & 1405 & 14.2 & 226 \\
3P1SDL & 2.4 & 0.17 & 1425 & 15.7 & 248 \\
\hline
\end{tabular}

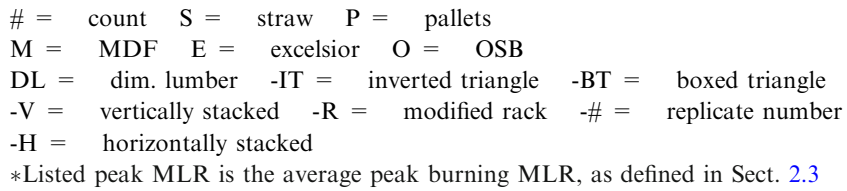

*Listed peak MLR is the average peak burning MLR, as defined in Sect. 2.3

\section{Results}

Tables 4 and 5 list the peak heat release rate, average peak burning mass loss rate, total energy release, effective heat of combustion, and peak burning duration for the 21 training fuel experiments and 12 comparison fuel (furniture) experiments, respectively. For complete time histories of the heat release rate, refer to the complete report [22].

\subsection{Repeatability of Base Fuel Package}

Three replicates of the base fuel package were compared (3P1S-1, 3P1S-2, and 3P1S-3). Figure 3 shows the HRR time histories for these replicates. The peak HRR among the three replicates ranged from $1.6 \mathrm{MW}$ to $2.1 \mathrm{MW}$, a $28 \%$ difference, which is greater than the measurement uncertainty. The peak burning dura- 


\section{Table 5}

Comparison Fuel Package Heat Release Rate (HRR) Characterization

\section{Results}

\begin{tabular}{lccccc}
\hline Label & $\begin{array}{c}\text { Peak HRR } \\
(\mathrm{MW})\end{array}$ & $\begin{array}{c}\text { Peak MLR* } \\
(\mathrm{kg} / \mathrm{s})\end{array}$ & $\begin{array}{c}\text { Total energy release } \\
(\mathrm{MJ})\end{array}$ & $\begin{array}{c}\Delta h_{c, e f f} \\
(\mathrm{MJ} / \mathrm{kg})\end{array}$ & $\begin{array}{c}\text { Peak burning duration } \\
(\mathrm{s})\end{array}$ \\
\hline SLI & 2.5 & 0.12 & 690 & 14.9 & 78 \\
SCI & 3.7 & 0.12 & 670 & 16.1 & 28 \\
SRI & 3.7 & 0.14 & 640 & 16.5 & 30 \\
SC-1 & 1.6 & 0.08 & 295 & 14.2 & 32 \\
SC-2 & 1.8 & 0.08 & 355 & 17.0 & 50 \\
SC-3 & 1.8 & 0.07 & 455 & 19.9 & 48 \\
YC-1 & 2.1 & 0.07 & 195 & 19.2 & 21 \\
YC-2 & 1.9 & 0.06 & 225 & 18.5 & 34 \\
B-1 & 2.2 & 0.10 & 935 & 19.3 & 176 \\
B-2 & 1.9 & 0.08 & 995 & 20.6 & 311 \\
BC-1 & 0.9 & 0.02 & 180 & 46.8 & 37 \\
KS-1 & 1.8 & 0.09 & 570 & 17.0 & 108 \\
\hline
\end{tabular}

$\mathrm{B}=$ bed $\mathrm{S}=$ upholstered sofa $\quad \mathrm{LI}=$ left ignition

$\mathrm{CI}=$ center ignition $\mathrm{RI}=$ right ignition $\mathrm{SC}=$ striped chair

$\mathrm{BC}=$ barrel chair $\mathrm{KS}=$ kit sofa $\mathrm{YC}=$ yellow chair

-\# = replicate number

*Listed peak MLR is the average peak burning MLR, as defined in Sect. 2.3

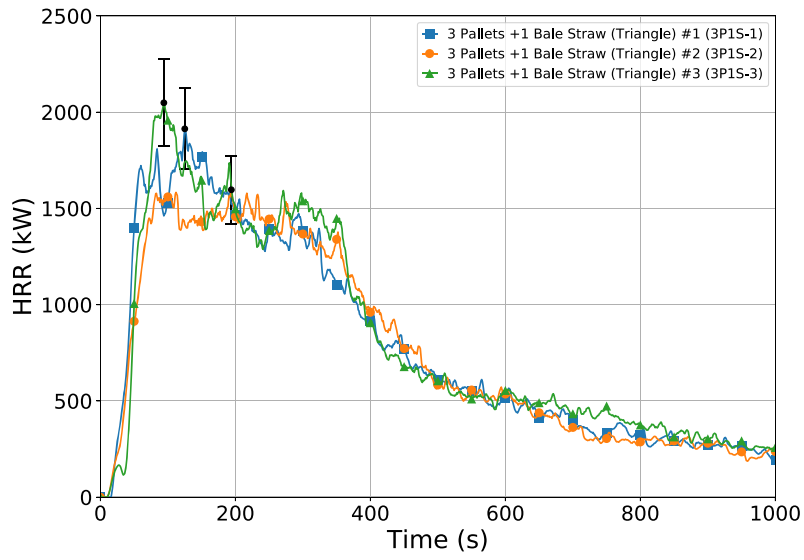

\section{Figure 3. Heat release rate (HRR) (kW) versus time for three} replicate experiments of the base fuel package.

tion ranged from $120 \mathrm{~s}$ to $291 \mathrm{~s}$, with the longest peak burning duration corresponding to the replicate with the lowest peak heat release rate, and the shortest peak burning duration corresponding to the replicate with the highest peak heat release rate. The replicates reached their peak burning period between $50 \mathrm{~s}$ and $75 \mathrm{~s}$ after ignition. Although the peak HRR and timing and duration of the peak burning duration varied, the total energy release among the three replicates was 
similar, ranging from $820 \mathrm{MJ}$ to $880 \mathrm{MJ}$, a $7 \%$ variation. The variation among the replicates was greatest in the first $100 \mathrm{~s}$ after ignition, when the straw was the primary fuel that is burning, indicating that the difference in initial growth likely reflects differences in the moisture content and packing density of the straw, which were not measured in these experiments. For the sake of comparison to other fuel packages, the median replicate, 3P1S-1, will be used for the remainder of the analysis.

\subsection{Linear Regression Analysis}

The effective heats of combustion of the training fuel packages were evaluated using Eq. 2. The values ranged from $12.4 \mathrm{MJ} / \mathrm{kg}$ to $16.4 \mathrm{MJ} / \mathrm{kg}$, a range which is consistent with $\Delta h_{c, \text { eff }}$ values commonly cited for wood [3]. Figure 4 shows the total energy release plotted against the mass burned for each of the training fuel packages.

Applying a linear regression to Fig. 4 results in a linear fit with a slope of 14.2 $\mathrm{MJ} / \mathrm{kg}$ and a $\mathrm{R}^{2}$ value of 0.980 , which shows that $\Delta h_{c, \text { eff }}$ is consistent between the different wood-based fuel packages and the variability in total energy released is largely described by changes in fuel mass burned. While some of the wood-based fuels, specifically the engineered wood products, contain synthetic

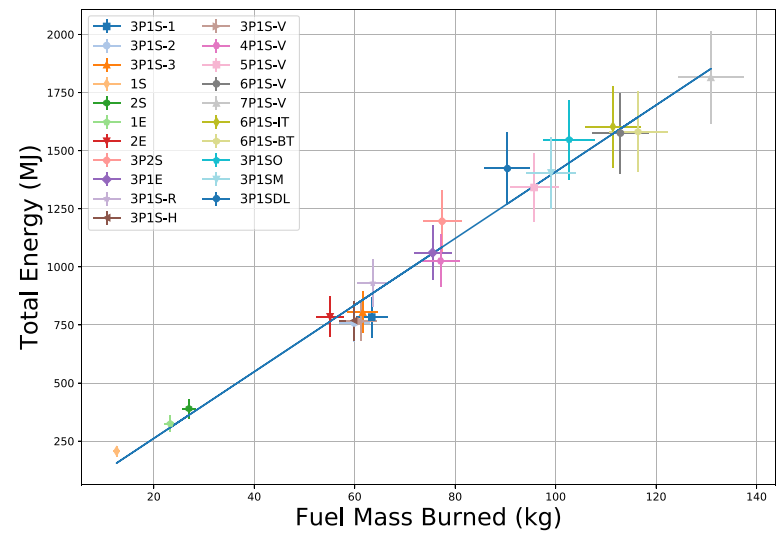

$\begin{array}{llllll}\text { Legend: } & & & & \\ \#= & \text { count } & \mathrm{S}= & \text { straw } & \mathrm{P}= & \text { pallets } \\ \mathrm{M}= & \mathrm{MDF} & \mathrm{E}= & \text { excelsior } & \mathrm{O}= & \text { OSB } \\ \mathrm{DL}= & \text { dim. lumber } & -\mathrm{IT}= & \text { inverted triangle } & -\mathrm{BT} & \text { boxed triangle } \\ & & & = & \\ -\mathrm{V}= & \text { vertically stacked } & -\mathrm{R}= & \text { modified rack } & -\#= & \text { replicate number } \\ -\mathrm{H}= & \begin{array}{l}\text { horizontally } \\ \text { stacked }\end{array} & & & \end{array}$

Figure 4. Comparison of total energy released and fuel mass burned for training fuel packages. The error bars corresponding to each point indicate the uncertainty of the measurement. 
resins which may have environmental or health effects [7], the majority of the fuel mass contributing to heat release rate is the wood component. The good linear fit between fuel mass burned and total energy release shows that the total energy did not vary substantially with the type of fuel (i.e. pallets, straw, excelsior, engineered wood) or the orientation of the fuel package (i.e. triangle, vertical stack horizontal stack, etc.).

Figure 5 shows the average HRR during the peak burning period plotted against the average MLR during the same period, using Dillon's definition of the peak burning period [6]. Similarly, applying a linear regression to Fig. 5 results in a linear fit with a slope of $14.9 \mathrm{MJ} / \mathrm{kg}$ and a $\mathrm{R}^{2}$ value of 0.99 . Consistent with Fig. 4, the good linear fit of peak burning HRR and MLR data shows that the variation of the heat of combustion is small among wood-based training fuels.

While the total energy release was directly related to the amount of fuel burned, and thus to the initial fuel mass, other quantities, such as the peak HRR and peak burning duration, were not as closely related to the initial mass. Figure 6, which compares the peak HRR with the initial fuel mass, shows that while the peak HRR can generally be expected to increase as fuel mass increases, the rela-

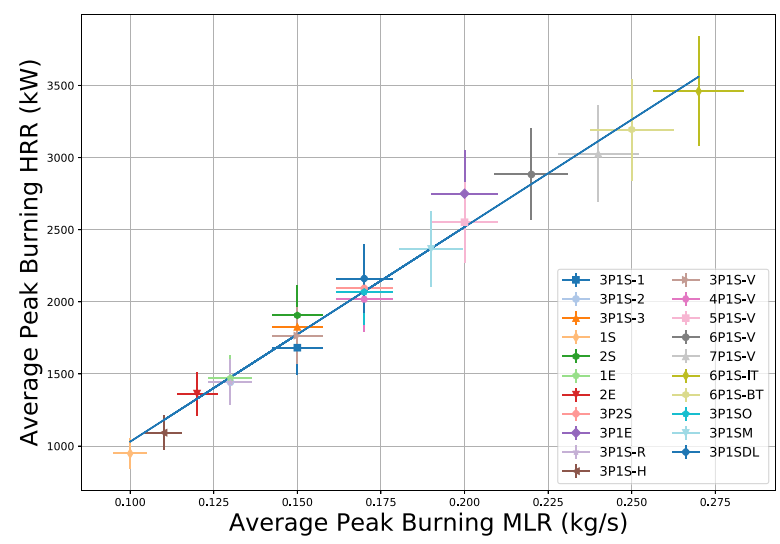

\begin{tabular}{llllll}
\hline Legend: & & & & \\
$\#=$ & count & $\mathrm{S}=$ & straw & $\mathrm{P}=$ & pallets \\
$\mathrm{M}=$ & $\mathrm{MDF}$ & $\mathrm{E}=$ & excelsior & $\mathrm{O}=$ & OSB \\
$\mathrm{DL}=$ & dim. lumber & $-\mathrm{IT}=$ & inverted triangle & $-\mathrm{BT}$ & boxed triangle \\
$-\mathrm{V}=$ & $\begin{array}{l}\text { vertically stacked } \\
\text { horizontally } \\
\text { stacked }\end{array}$ & $-\mathrm{R}=$ & modified rack & $-\#=$ & replicate number \\
$-\mathrm{H}=$ & & & \\
\hline
\end{tabular}

Figure 5. Comparison of average mass loss rate (MLR) and average heat release rate (HRR) over the peak burning period for training fuel packages. Peak burning period is defined as the period in which the HRR is greater than or equal to $80 \%$ of the peak HRR [6]. The error bars corresponding to each point indicate the uncertainty of the measurement. 


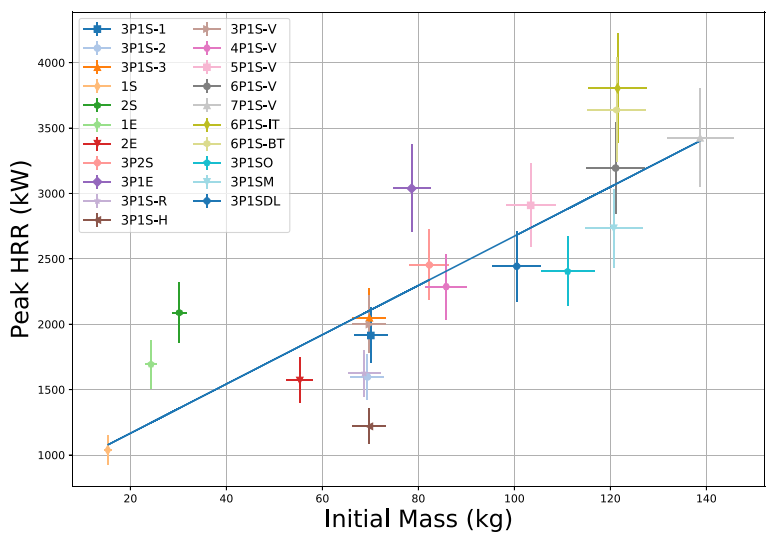

\begin{tabular}{llllll}
\hline Legend: & & & & \\
$\#=$ & count & $\mathrm{S}=$ & straw & $\mathrm{P}=$ & pallets \\
$\mathrm{M}=$ & $\mathrm{MDF}$ & $\mathrm{E}=$ & excelsior & $\mathrm{O}=$ & $\mathrm{OSB}$ \\
$\mathrm{DL}=$ & dim. lumber & $-\mathrm{IT}=$ & inverted triangle & $-\mathrm{BT}=$ & boxed triangle \\
$-\mathrm{V}=$ & vertically stacked & $-\mathrm{R}=$ & modified rack & $-\#=$ & replicate number \\
$-\mathrm{H}=$ & $\begin{array}{l}\text { horizontally } \\
\text { stacked }\end{array}$ & & & & \\
\hline
\end{tabular}

Figure 6. Peak heat release rate (HRR) vs. initial fuel mass for wood-based training fuel packages. The black line represents an ordinary least squares regression. The error bars corresponding to each point indicate the uncertainty of the measurement.

tionship is more variable than between total energy and fuel mass burned, with an $\mathrm{R}^{2}$ of 0.672 .

\subsection{Comparison Fuels (Furniture)}

The peak HRR, average peak burning MLR, total energy release, effective heat of combustion, and peak burning duration for the comparison fuel packages are listed in Table 5. The effective heat of combustion for the comparison fuel packages ranged from $14.2 \mathrm{MJ} / \mathrm{kg}$ to $46.8 \mathrm{MJ} / \mathrm{kg}$. The barrel chair (BC-1) had the highest effective heat of combustion out of the fuel packages tested, nearly twice the value of the remainder of the fuel packages.

The upholstered sofa had the highest peak HRR of the furniture items evaluated here. One of the three replicates had a lower peak HRR, $2.5 \mathrm{MW}$, than the other two replicates, which both had peaks of $3.7 \mathrm{MW}$, a difference of $51 \%$. Although the peak HRRs varied, the total energy releases were comparable, ranging from $640 \mathrm{MJ}$ to $690 \mathrm{MJ}$, a difference of $8 \%$. The upholstered sofas reached their peak burning periods between $315 \mathrm{~s}$ and $400 \mathrm{~s}$ after ignition.

The two types of upholstered chairs (SC and YC) had peak heat release rates ranging from 1.6 MW to 2.1 MW. Although the YC replicates had a lower initial mass $(24.8 \mathrm{~kg}$ and $25.9 \mathrm{~kg}$ ), they exhibited slightly higher peak HRRs than the SC design, which had masses between $27.8 \mathrm{~kg}$ and $28.4 \mathrm{~kg}$. The YC replicates had 
total energy releases of $195 \mathrm{MJ}$ and $225 \mathrm{MJ}$, which varied by $15 \%$. The total energy release of the SC replicates varied more considerably, ranging from $295 \mathrm{MJ}$ to $455 \mathrm{MJ}$ (50\% variation). The kit sofa had a peak HRR in the same range as the upholstered chairs $(1.8 \mathrm{MW})$ although the total energy release (570 MJ) and peak burning duration (108 s) were longer. The barrel chair had the lowest peak HRR (0.9 MW) and total energy release (177 MJ) of all the furniture items evaluated.

The bedsets had peak HRRs comparable to the upholstered chairs, but total energy releases that were almost twice as high. Further, the bedsets had the longest peak burning period of the furniture items, $176 \mathrm{~s}$ and $311 \mathrm{~s}$, for the first and second replicates, respectively. The higher total energy release and longer peak burning duration reflect the higher initial mass of the bedsets compared to the upholstered sofas and chairs.

\section{Discussion}

\subsection{Relevance to NFPA 1403}

Instructors and training academies currently rely on the mass or quantity of fuel to estimate the thermal conditions that will be produced within the training structure. The large deviation from a linear relationship between peak HRR and initial fuel mass indicates that factors other than the initial mass, particularly the orientation of the fuel, play an important role in determining the peak HRR of the fuel package.

This is important in the context of NFPA 1403, which provides a methodology for designing ventilation-limited fire training scenarios based on the peak HRR of training fuel packages, but provides no data to guide the selection of a training fuel package. While previous research has produced a limited amount of data regarding the peak HRR of training fuel packages, these fuel packages have often been in simple stack or triangle formations. Since fuel mass alone cannot reliably predict the peak HRR of a training fuel package, it would be beneficial to develop a catalog of fuel packages with different orientations and quantities of woodbased fuels to better enable instructors to predict the peak HRR under fuel-controlled conditions. Further, while the linear relationship between average peak burning MLR and average peak burning HRR was established with minimal variability, the MLR is an impractical measurement for fire instructors to assess in the field.

Consider as an example the six fuel packages consisting of three pallets with one bale of straw, which varied in initial mass from $69.4 \mathrm{~kg}$ to $70.1 \mathrm{~kg}$. The peak HRR of these fuel packages varied from 1.2 MW to $2.1 \mathrm{MW}$ (75\% difference). This difference, including the difference among the three replicate fuel packages in the triangle orientation, is greater than the uncertainty of the HRR measurement, indicating that the changes in orientation can significantly impact the peak HRR. The triangle and vertical stack orientations had comparatively higher HRRs (1.9 MW-2.1 MW) than the horizontal and rack configurations (1.2 MW and 1.6 MW, respectively). Similarly, the fuel packages consisting of three pallets, one 
bale of straw and two sheets of MDF (3P1SM) and six pallets and one bale of straw stacked two layers high (6P1S-IT) had comparable initial masses of $120.8 \mathrm{~kg}$ and $121.5 \mathrm{~kg}$, respectively, but the peak heat release rate of the six pallet configuration was $0.9 \mathrm{MW}(39 \%)$ higher than the pallets, straw, and MDF.

These variations in peak HRR show that it is not just the amount of fuel, but also the types of wood-based fuels that the fuel package includes. The training fuel packages with OSB, MDF and dimensional lumber were comparable in mass $(100.5 \mathrm{~kg}-120.8 \mathrm{~kg})$ to the fuel packages with five- and six-vertically stacked pallets $(103.4 \mathrm{~kg}$ and $121.1 \mathrm{~kg}$, respectively), but had lower peak HRRs. The OSB, MDF, and dimensional lumber fuel packages had peak HRRs of $2.4 \mathrm{MW}$, $2.4 \mathrm{MW}$, and $2.7 \mathrm{MW}$, respectively, compared to peak HRRs of $2.9 \mathrm{MW}$ and 3.2 MW for the five- and six-pallet configurations, respectively.

Knowledge of the peak HRR of training fuel packages is a crucial step in providing instructors with a quantitative means of predicting fire behavior in training evolutions. Use of these values, in conjunction with Eq. 1 allows instructors to estimate the minimum heat release rate required for flashover in the burn room of their acquired structure or fixed-facility training building based on ventilation openings, then select a fuel package that matches the training objectives related to flashover. While this is an important step towards quantitative methods of selecting training fuel packages, the fuel package used in a training evolution is not the sole predictor of fire behavior. Indeed, previous research examined the thermal conditions produced by a training fuel package similar to the base fuel package in different types of live fire training buildings, and demonstrated that the lining material affected the thermal conditions $[21,25,30]$. A fuel package similar to the base fuel package did not generate flashover conditions in the burn room of a concrete live fire training building, but did generate flashover conditions in a gypsum-lined compartment. Further research is needed to evaluate the suitability of this equation for predicting flashover using wood-based training fuels in training structures of various sizes and constructed using different buildings materials.

\subsection{Repeatability of Training Fuel Packages}

Among the justifications for specifying the use of wood-based fuels in training fuel packages is the belief that these fuels produce repeatable, predictable fire behavior. The peak HRRs observed for the four and five pallet vertical stacks were comparable to previous free burn HRR evaluations conducted on similar wood based training fuel packages. Madrzykowski [15] conducted a set of three replicate experiments using a training fuel package of five vertically stacked pallets with one bale of straw, which yielded an average peak HRR of $2.8 \mathrm{MW}$. The 5P1S fuel package exhibited a comparable peak HRR of $2.9 \mathrm{MW}$.

The peak HRR of the fuel package consisting of three pallets with one bale of straw (3P1S-1, 3P1S-2, and 3P1S-3) varied by $28 \%$ among the three replicates, which was greater than the uncertainty of the HRR measurement. While this was less than the variability observed among the three replicate experiments of the upholstered sofa (SLI, SCI, SRI), which was $51 \%$, it was greater than the variability in peak HRR observed among the replicates of the striped chair, yellow 
chair, and bed were $13 \%, 11 \%$, and $16 \%$, respectively. The greater variability of the peak HRR of the training fuel package reflects differences in moisture content, packing density, and orientation in fuel packages composed of wood-based materials which are not present in manufactured, upholstered furniture. Further research is needed to investigate the effects of these parameters on the growth of training fuel packages and the implications of these differences for live fire training.

\subsection{Comparison of Training Fuels and Furnishings}

While NFPA 1403 specifies that only wood-based training fuels are permissible for use in live-fire training, the fuels that firefighters are likely to encounter in residential structures are more likely to be similar to the synthetic furnishings described in Table 3. The $\Delta h_{c, e f f}$ values estimated for furniture fuel packages were higher than those estimated for the wood-based training fuel packages, ranging from $14.9 \mathrm{MJ} / \mathrm{kg}$ to $46.8 \mathrm{MJ} / \mathrm{kg}$. Although the $\Delta h_{c, e f f}$ of the furniture items were higher, wood-based training fuel packages produced peak HRRs consistent with individual furniture items, as shown in Fig. 7.

The three upholstered sofas had the highest peak HRR of the synthetic fuel packages. One of the sofa replicates had a significantly lower peak than the other two experiments-2.5 MW compared to $3.7 \mathrm{MW}$. The sofa with a peak HRR of $2.5 \mathrm{MW}$ was comparable to training fuel packages in the $80 \mathrm{~kg}-115 \mathrm{~kg}$ range, including several fuel packages that utilized three pallets (3P2S, 3P1S, 3P1SDL). The upholstered sofas which exhibited HRRs of $3.7 \mathrm{MW}$ were comparable to

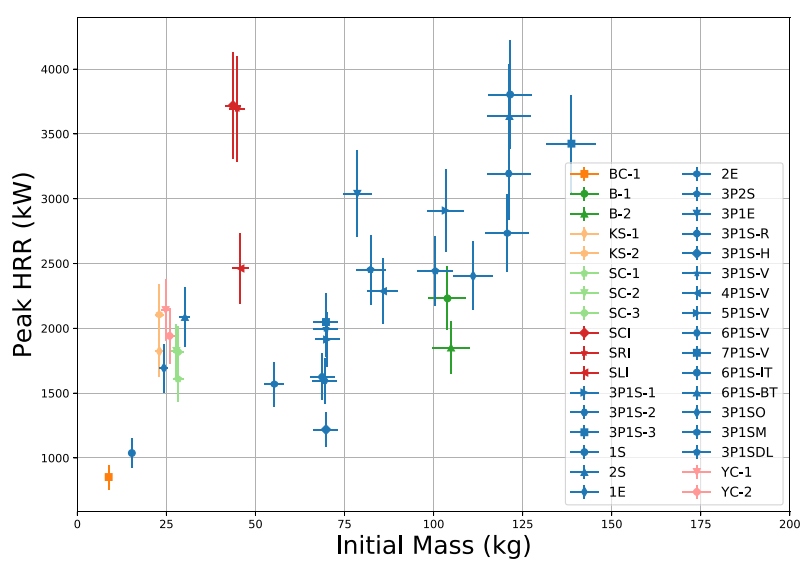

Figure 7. Peak HRR (kW) versus initial mass for wood-based and synthetic fuels. Blue markers denote wood-based training fuel packages, red markers denote upholstered sofas, dark green markers denote bed sets, pink and light green markers denote upholstered chairs, orange markers denote barrel chairs, and yellow markers denote kit sofas. The error bars corresponding to each point indicate the uncertainty of the measurement. 
training fuel loads in the $120 \mathrm{~kg}-140 \mathrm{~kg}$ range, which includes the fuel packages with 6 or 7 pallets and one bale of straw. The peak HRRs of the remainder of the synthetic furnishings, including the upholstered chairs, kit sofa, and bed sets, was grouped between 1.6 MW and 2.2 MW. This range of peak HRRs makes them comparable to training fuel packages consisting of 2 bales of straw, 1-2 bales of excelsior, or 3-4 pallets with one bale of straw, with initial masses ranging from $20 \mathrm{~kg}$ to $85 \mathrm{~kg}$.

Although training fuel packages produce comparable peak HRRs to individual furniture items, there are several important distinctions between wood-based training fuels and their synthetic counterparts. The fuel load in a typical residential room would often consist of more than a single item of furniture. Experiments conducted by Weinschenk et al examined the HRR of a $3.65 \mathrm{~m} \times 3.65 \mathrm{~m}$ room furnished with two upholstered sofas, carpet, and carpet padding [28]. Each of these rooms transitioned through flashover, with peak HRRs ranging from 6.2 MW to 7.0 MW. Although the peak HRR observed in these residential rooms with multiple furniture items was higher than individual training fuel packages, it is important to note that wood-based training fuel packages are capable of producing flashover in residential-sized rooms [15].

Additionally, there was a distinct visual difference between the burning of the training fuel packages and furniture items. Figure 8 shows still images of the six pallet boxed-in triangle (6P1S-BT) and one of the upholstered sofa replicates (SCI) at the time of their peak HRR. Although the peak HRRs were comparable between the two (3.6 MW and 3.7 MW for 6P1S-BT and SCI, respectively), the upholstered sofa produced a greater quantity of soot, which obscured the lighting in the laboratory - an effect not observed in the fuel package consisting only of pallets and straw. This is due, in part, to the higher soot yield of synthetic materials compared to wood. The soot yields during well-ventilated combustion of different types of flexible polyurethane foam range from $0.131 \mathrm{~g} / \mathrm{g}$ to $0.227 \mathrm{~g} / \mathrm{g}$, compared to $0.015 \mathrm{~g} / \mathrm{g}$ for wood species [14]. In addition to having a greater soot yield, synthetic fuels, such as polyurethane foam, produce higher yields of unburned hydrocarbons, which have the potential to sustain further burning. Under ventilation-controlled conditions, such as those likely to be encountered at a residential structure fire [12], this would be especially true. The flashover hazard posed to firefighters by unburned hydrocarbons in smoke is among the reasons
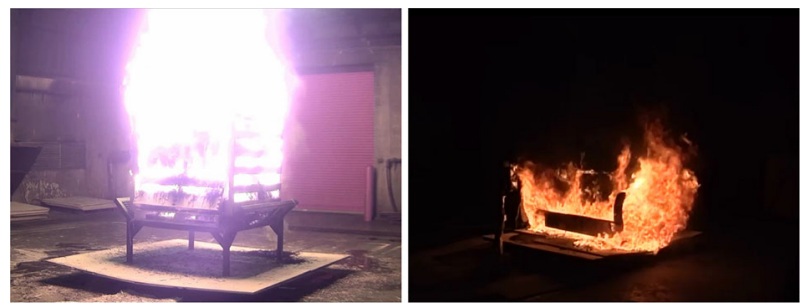

Figure 8. Visual comparison of six pallet boxed-in triangle (6P $1 \mathrm{~S}$ BT) and upholstered sofa (SCl) fuel package experiments at time of peak HRR (3.6 MW and 3.7 MW, respectively). 
that synthetic materials, such as polyurethane foam, are prohibited as fuels in NFPA 1403.

An additional distinction between the furniture items and the training fuels of a comparable peak HRR is the total energy release. This trend can be seen by comparing the values in Tables 4 and 5, which show that training fuel packages exhibited considerably higher total energy releases and longer peak burning periods than corresponding furniture items. Most furniture items were generally characterized by a slow initial growth, followed by rapid growth to a brief peak burning period beginning $150 \mathrm{~s}-350 \mathrm{~s}$ after ignition. The notable exception to this was the two bedsets that were evaluated, which had a long peak burning duration which started at least $400 \mathrm{~s}$ after ignition. The training fuel packages which had peak HRRs similar to the sofas and chairs exhibited total energy releases of $1195 \mathrm{MJ}-$ $1815 \mathrm{MJ}$, whereas the total energy release of the furniture items was considerably lower, ranging from $215 \mathrm{MJ}$ to $695 \mathrm{MJ}$.

The higher total energy release required for NFPA 1403-compliant training fuel packages compared to furniture with a similar peak HRR has important implications for firefighter training. The extended peak burning period has the potential to produce elevated heat flux values for extended periods of time [21]. Unlike in an actual incident response, training fire evolutions will likely require personnel in the interior of the training structure for extended period of time, acting as safety officers or as members of the ignition team [17]. These extended exposures have the potential to cause injury or death to firefighters acting in these capacities. In 2005, a fire instructor in Pennsylvania died during a day-long "train the trainer" class. The instructor had been rebuilding the fire after each evolution during the day and had been in the process of adding pallets to the training fuel package when his SCBA facepiece failed from the hot gases. A recreation of the incident conducted by NIST indicated that the temperature and heat flux $5.00 \mathrm{ft}(1.50 \mathrm{~m})$ above the floor in the basement of the fire training building exceeded $932^{\circ} \mathrm{F}$ $\left(500^{\circ} \mathrm{C}\right)$ and of $20 \mathrm{~kW} / \mathrm{m}^{2}$ [15]. These thermal conditions, which exceed the protective capabilities of firefighter PPE, were created using NFPA 1403-compliant training fuels, highlighting the importance of using quantitative guidance when determining the appropriate training fuel package for training fires.

\subsection{Future Research}

Further research is needed to improve the fire service's ability to apply Equation 1 in designing live fire training evolutions using NFPA 1403-compliant, wood based training fuel packages. Experiments should be conducted to better understand how different sizes of compartment and different ventilation configurations affect the propensity of training fuel packages to produce ventilation-controlled fire behavior. Additionally, future work should include replicate experiments to assess the repeatability of heat release behavior among training fuel packages, as well as to determine the effects of moisture content and packing density. 


\section{Conclusions}

Live fire training environments can vary considerably depending on the type of training fuel package chosen for use by fire instructors. The results of these experiments showed that wood-based, NFPA 1403-compliant training fuel packages ranging in mass from $15 \mathrm{~kg}$ to $103 \mathrm{~kg}$ produced peak free burn heat release rates ranging from 1.0 MW to $3.8 \mathrm{MW}$, with total energy releases ranging from $210 \mathrm{MJ}$ to $1815 \mathrm{MJ}$. While peak HRR generally increased as fuel mass increased, the effects of orientation were considerable, with the peak HRRs of similarly sized training fuel packages varying by nearly $1 \mathrm{MW}$. Since the initial mass of fuel packages alone is not a reliable predictor of peak HRR, a "catalog" style approach is the current state of the art for quantitative guidance on training fuel packages. With this method, instructors can use guidance from experimental data on peak HRR and the timing and length of the peak burning period to tailor fuel loads to the training buildings and learning objectives that they will be used to satisfy.

Furniture items including upholstered chairs and sofas ranging in mass from $9 \mathrm{~kg}$ to $105 \mathrm{~kg}$ produced peak HRRs ranging from $0.9 \mathrm{MW}$ to $3.7 \mathrm{MW}$, with total energy releases ranging from $180 \mathrm{MJ}$ to $995 \mathrm{MJ}$. While large wood-based training fuel packages may have comparable peak HRRs to individual pieces of furniture, they often have a longer peak burning duration and a higher total energy release as a result of the higher fuel package mass.

\section{Acknowledgements}

The author would like to thank the Department of Homeland Security's Assistance to Firefighters Grant Program (Grant \\# EMW-2014-FP-00471) for making this work possible. The author thanks Kelly Opert and the technical staff of the UL LLC large fire laboratory for their assistance with preparing and conducting the free burn HRR experiments. Without their hard work, none of these experiments would have been possible. Special thanks to Gavin Horn and Dan Madrzykowski for their time and help with technical reviews of this manuscript. Finally, thanks to Keith Stakes, Joseph Willi, and Robin Zevotek for their work in planning these experiments.

\section{Open Access}

This article is licensed under a Creative Commons Attribution 4.0 International License, which permits use, sharing, adaptation, distribution and reproduction in any medium or format, as long as you give appropriate credit to the original author(s) and the source, provide a link to the Creative Commons licence, and indicate if changes were made. The images or other third party material in this article are included in the article's Creative Commons licence, unless indicated otherwise in a credit line to the material. If material is not included in the article's 
Creative Commons licence and your intended use is not permitted by statutory regulation or exceeds the permitted use, you will need to obtain permission directly from the copyright holder. To view a copy of this licence, visit http://creat ivecommons.org/licenses/by/4.0/.

\section{References}

1. Averill JD, Moore-Merrell L, Barowy A, Santos R, Peacock R, Notarianni KA, Wissoker D (2010) Report on residential fireground field experiments. NIST Technical Note 1661, National Institute of Standards and Technology, Gaithersburg, Maryland

2. Babrauskas V (1980) Estimating room flashover potential. Fire Technol 16:94-103

3. Babrauskas V, Grayson S (1990) Heat release in fires. Taylor, London

4. Bryant R, Mullholland G (2008) A guide to characterizing heat release rate measurement uncertainty for full-scale fire tests. Fire Mater 32:121-139

5. Demers Associates Inc (1982) Two die in smoke training drill. Fire Service Today, pp $17-20$

6. Dillon S, Kim W, Quintiere J (1998) Determination of properties and the prediction of the energy release rate of materials in the ISO 9705 room-corner test. NIST NISTGCR-98-753, National Institute of Standards and Technology, Gaithersburg

7. Fent KW, Mayer A, Bertke S, Kerber S, Smith D, Horn G (2019) Understanding airborne contaminants produced by different fuel packages during training fires. J Occup Environ Hyg (2019)

8. Fisher G (2015) Conducting NFPA 1403-compliant live burn training in acquired structures. Fire Engineering

9. Garcia K, Kauffman R (2009) Realistic live burn training you can afford. Fire Engineering

10. Horn G, Stewart J, Kesler R, DeBlois J, Kerber S, Fent K, Scott W, Fernhall B, Smith D (2019) Fire fighter and fire instructor's physiological responses and safety in various training environments. Saf Sci 116:287-294

11. Karsner L (1968) Burning characteristics of wooden pallets as a test fuel. Progress report serial no. 16437, Factory Mutual Research Corporation, Norwood

12. Kerber S (2012) Analysis of changing residential fire dynamics and its implications on firefighter operational timeframes. Fire Technol 48:865-891

13. Kerber S (2012) Impact of ventilation on fire behavior in legacy and contemporary residential construction. Underwriters Laboratories, Northbrook

14. Khan M, Tewarson A, Chaos M (2002) SFPE handbook of fire protection engineering, 3 rd edn, chap. Combustion characteristics of materials and generation of fire products. National Fire Protection Association, Quincy, Massachusetts

15. Madryzkowski D (2007) Fatal training fires: fire analysis for the fire service. In: INTERFLAM 2007 proceedings. Interscience Communications Ltd (2007)

16. Madrzykowski D (2017) Fire fighter equipment operational environment: evaluation of thermal conditions. Fire Protection Research Foundation, Quincy

17. National Fire Protection Association, Quincy, Massachusetts: NFPA 1403: Standard on Live Fire Training Evolutions (2018)

18. Ohaus Corporation, Pine brook, New Jersey: Manual for SD Series Bench Scale (2000)

19. Parker W (1984) Calculation of the heat release rate by oxygen consumption for various applications. J Fire Sci 2:380-395

20. Reeder F (2013) The NFPA 1403 debate. Fire Rescue 
21. Regan J, Zevotek R (2018) Study of the fire service training environment: safety and fidelity in concrete live fire training buildings. Underwriters Laboratories, Columbia

22. Regan J, Zevotek R (2019) Evaluation of the thermal conditions and smoke obscuration of live fire training fuel packages. Underwriters Laboratories, Columbia

23. Romano N, Tarley J (2002) Career lieutenant and fire fighter die in a flashover during a live-fire training evolution - Florida. NIOSH F2002-34, National Institute for Occupational Safety and Health

24. Rossi R (2003) Fire fighting and its influence on the body. National Institute for Occupational Safety and Health

25. Stakes K, Willi J (2019) Study of the fire service training environment: safety, fidelity, and exposure-cquired structures. Underwriters Laboratories, UL Firefighter Safety Research Institute, Columbia, Maryland

26. Tarley J (2007) Career probationary fire fighter dies while participating in a live-fire training evolution at an acquired structure - Maryland. NIOSH F2007-09, National Institute for Occupational Safety and Health

27. Tarley J, Mezzanotte T (2001) Volunteer fire fighter dies and two others are injured during live-burn training - New York. NIOSH F2001-38, National Institute for Occupational Safety and Health

28. Weinschenk C, Madrzykowski D, Courtney P (2019) Impact of flashover fire conditions on exposed energized electrical cords/cables. Fire Technol 56:959-991

29. Willi J, Horn G, Madrzykowski D (2016) Characterizing a Firefighter's immediate thermal environment in live-fire training scenarios. Fire Technol 52(6):1339-1350

30. Willi J, Stakes K, Regan J, Zevotek R (2018) Evaluation of ventilation-controlled fires in L-shaped training props. Underwriters Laboratories, Columbia

Publisher's Note Springer Nature remains neutral with regard to jurisdictional claims in published maps and institutional affiliations. 